DOI https://doi.org/10.32782/2305-9389/2020.23.06

УДК 323.21

Баковецька Ольга,

докторка історичних наук, професорка за наказом кафедри інформачійної, бібліотечної та архівної справи

Миколаївської філії Київського національного університету культури і мистецтв

\title{
ВОЛОНТЕРСЬКИЙ РУХ В УКРАЇНІ НА СУЧАСНОМУ ЕТАПІ РОЗВИТКУ
}

Стаття присвячена проблемі розвитку волонтерського руху на території сучасної Украӥни. У матеріалі визначено, ще волонтерський рух на украӥнських землях має глибоке коріння й усталену традицію спільної добровільної допомоги один одному в разі критичної ситуаиії та у важкі часи. Висвітлено причини активізаиї волонтерства в Украӥні у XXI столітті, зокрема, яку роль відіграли в иььму процесі Революиія Гідності та війна на сході Украӥни. На основі статистичних даних визначено рівень залученості громадян до волонтерського руху та готовності українців робити благодійні внески, ступінь довіри суспільства до волонтерських організацій, а також місие, яке посідає Україна в щзорічному дослідженні благодійності у світі (World Giving Index), яке проводить Charities Aid Foundation. У роботі проаналізовано вітчизняне законодавство, щзо регламентує діяльність волонтерських та благодійних організаџій. Визнання на державному рівні волонтерство в Україні отримало у 2003 роиі у відповідній постанові Кабінету Міністрів. Закон Украӥни «Про волонтерську діяльність» прийнято лише у 2011 роиі. Цим законодавча база волонтерського руху не вичерпується. У прочесі спільної роботи державних органів влади та представників громадської ініціативи постійно вносяться корективи, доповнення до чинного законодавства з означеної проблеми. У статті визначено основні напрями діяльності громадян та організацій, задіяних у волонтерському русі. Визначено сфери, в яких найчастіше реалізується благодійницька та волонтерська діяльність. Крім того, на основі статистичних даних чітко простежується тендениія значної переваги в кількісному співвідношенні волонтерських організацій над благодійними. Підкреслено роль, яку вони відіграли у вирішенні болючих проблем, щзо спіткали суспільство та державу. У статті використано статистичні дані для визначення рівня допомоги волонтерських організачій. Наведено приклади діяльності окремих волонтерських організацій. Окрему увагу приділено розвитку волонтерського руху на території Миколаївщини. Визначено проблеми, з якими стикався та продовжує стикатися волонтерський рух в Украӥні.

Ключові слова: волонтерський рух, благодійність, Револючія Гідності, війна на сході Украӥни, громадянське суспільство.

\section{Bakovetska Olha. Volunteer movement in Ukraine at the present stage of development}

The article is devoted to the problem of development of the volunteer movement on the territory of modern Ukraine. The material states that the volunteer movement in the Ukrainian lands has deep roots and a well-established tradition of joint voluntary assistance to each other in case of crisis and in difficult times. The reasons for the intensification of volunteering in Ukraine in the XXI century are highlighted, in particular, what role the Revolution of Dignity and the war in eastern Ukraine played in this process. Based on statistics, the level of citizen involvement in the volunteer movement and the willingness of Ukrainians to make charitable contributions, the degree of public confidence in volunteer organizations and Ukraine's place in the Charity Aid Foundation's annual World Giving Index survey are determined. The paper analyzes the domestic legislation governing the activities of volunteer and charitable organizations. At the state level, volunteering in Ukraine was recognized in 2003 in a relevant resolution of the Cabinet of Ministers. The Law of Ukraine "On Volunteering" was adopted only in 2011. This does not exhaust the legal framework of the volunteer movement. In the process of joint work of state authorities and representatives of the public initiative, adjustments and additions to the existing legislation on this issue are constantly made. The article identifies the main activities of citizens and organizations involved in the volunteer movement. The areas in which charitable and volunteer activities are most often identified are identified. In addition, based on statistics, there is a clear trend of a significant advantage in the quantitative ratio of volunteer organizations over charities. The role they played in solving the painful problems that befell society and the state was emphasized. The article uses statistics to determine the level of assistance of volunteer organizations. Examples of activity of separate volunteer organizations are given. Particular attention is paid to the development of the volunteer movement in the territory of Mykolayiv region. The problems that the volunteer movement in Ukraine has faced and continues to face have been identified.

Key words: volunteer movement, charity, Revolution of Dignity, the war in eastern Ukraine, civil society.

Волонтерський рух - явище унікальне. Рівень участі громади в ньому є показником зрілості та відповідальності суспільства, усвідомленого ставлення до викликів, які пропонує нам життя, готовності вирішувати актуальні проблеми спільними зусиллями. Останнім часом таких викликів стає дедалі більше. I від згуртованості людей, нашого вміння та бажання брати участь у житті громади, в тому 
числі через волонтерську діяльність, залежить наше майбутнє. Отже, дослідження волонтерського руху $\epsilon$ актуальною та перспективною темою.

Мета статті полягає в дослідженні пріоритетних напрямів розвитку волонтерського руху в Україні на сучасному етапі.

Дослідження визначеної проблематики знаходиться на стадії свого розвитку. 3 активізацією волонтерського руху збільшилась і кількість наукових розвідок. Останнім часом з'явились роботи відповідної тематики таких науковців: О. Балухтіна [1], В. Голуб [2], Єсіна Н. [3], Л. Кожухаренко [4]. Виходять збірки про історію та діяльність волонтерів сьогодення [5], проводяться всеукраїнські статистичні дослідження, наприклад «Діяльність українських благодійних організацій», виконане CORESTONE GROUP та GFK UKRAINE на замовлення Фонду родини Загорій [6], розробляються аналітичні доповіді [7].

Волонтерство розуміється як добровільна, безкорисна діяльність людини, що має важливе значення для суспільства. В історії України волонтерський рух має глибоке коріння. 3 давніх часів відоме таке явище, як братчина, складчина, меценатська, добродійна та благодійна діяльність. У ній брали участь окремі особи, релігійні та світські організації, що опікувалися освітою, притулками, лікарнями, їдальнями для малозабезпечених прошарків населення [8]. Волонтерство $є$ продовженням благодійної діяльності, окремою формою благодійності, що почала розвиватися з XIX століття. Її особливість полягає в наданні добровільних, безоплатних послуг нужденним, виконання робіт на їх користь.

До 2014 року волонтерський рух в Україні розвивався досить слабо, порівняно з іншими країнами світу. Згідно з рейтингом World Giving Index в 2010 році Україна займала лише 150 місце (тільки 5\% населення було залучено до волонтерської роботи) [9]. Активізація волонтерського руху в Україні на сучасному етапі пов'язана з Революцією Гідності та початком війни на сході країни. Саме в цей складний час суспільство згуртувалося, створено цілу мережу громадських організацій, що взяли на себе відповідальність за постачання необхідного продовольства, медикаментів, військового обладнання. Активна суспільна позиція окремих громадян, громадських організацій дала змогу державі вистояти в складний час та вирішити актуальні проблеми.

20-26 листопада 2014 року за допомогою методології САТІ (телефонні інтерв’ю, дзвінки на мобільні номери) було проведено дослідження стану волонтерства майже по всій території України, без Криму. Було опитано 1000 респондентів. Дослідження проведене Представництвом Організації Об'єднаних Націй та Програмою «Волонтери ООН» за фінансової підтримки Міністерства закордонних справ Данії. Згідно з висновками опитування, $62 \%$ українців визнавали значну роль волонтерів у політичних змінах, $85 \%$ вважали, що волонтерський рух допомагає зміцненню миру, а 81\% переконані, що волонтерський рух $є$ обов'язковою складовою частиною громадянського суспільства. Майже чверть українців (23\%) мали досвід волонтерства, із них 9\% почали займатись волонтерством протягом 2014 року. Основним напрямом діяльності волонтерів у 2014 році стала допомога українській армії та пораненим - цим займались 70\% волонтерів. 74\% українців жертвували кошти на різні цілі коли-небудь у житті, з яких 25\% почали жертвувати тільки протягом останніх 12 місяців 2014 року [10].

Отже, внаслідок Революції Гідності та війні на сході громадяни максимально мобілізували сили на допомогу учасникам революції та військовим у зоні АТО, пораненим, а також мирному населенню, яке постраждало через військовий конфлікт. Це вплинуло на зміну місця України в рейтингу World Giving Index - щорічному дослідженні благодійності у світі, яке проводить Charities Aid Foundation (CAF): 3 позначки 103 у 2014 році ми перейшли до 89-ї позиції у 2015 році. Однак у 2016 році позиція України в рейтингу впала до 105 місця через зменшення показників волонтерства та надання допомоги незнайомцям. Разом із тим суми грошових пожертв зросли [11]. У 2019 році згідно із 10 виданням Всесвітнього рейтингу благодійності СAF, в якому охоплено 10 років опитувань, з 2009 по 2018 рік, Україна займає 101 позицію [12].

За даними загальнонаціональних досліджень, проведених Фондом «Демократичні ініціативи» імені Ілька Кучеріва спільно з соціологічною службою Центру Разумкова, найвищого показника участь громадян у благодійній діяльності досягла після Революції гідності. Так, 47\% опитуваних у 2015 році надавали грошову чи матеріальну допомогу конкретним людям чи організаціям. Щоправда, далі цей відсоток почав знижуватися: 42\% у 2016 році, 41\% - у 2017, 38,5\% - у 2018 [9] і 20,9\% - у 2020 р. [13]. Поряд із тенденцією зменшення активності людей, опитування, проведене навесні 2020 року, показало, що $37 \%$ громадян, на думку експертів, готові давати гроші на те, що вони вважають важливим [14]. Водночас рівень залученості до благодійної діяльності нині все ж залишається вищим, ніж до Революції Гідності. Загальна сума, яку благодійники жертвували впродовж 2018 року, дещо зросла порівняно з попередніми роками. У 2017 році основна сума пожертвувань припадала на суми від 50 до 300 гривень, а в 2018 році - від 50 до 500 гривень [11]. 
Крім того, згідно з опитуванням, проведеним соціологічною службою Центру Разумкова у квітні 2017 року, серед державних та суспільних інституцій найбільшою довірою громадян користувались волонтерські організації (їм довіряли 66\% опитаних). Далі йдуть церква (63,3\%), 3бройні сили України (55,9\%), Нацгвардія (49\%) [15]. Подібне опитування, проведене з 21 по 26 березня 2019 року, підтвердило, що найчастіше громадяни України висловлюють довіру волонтерським організаціям (їм довіряли 68\% опитаних), церкві (61\%), Збройним силам України (61\%), Державній службі з надзвичайних ситуацій (57\%), добровольчим батальйонам (56\%), Державній прикордонній службі (52\%), Національній гвардії України (49\%), ЗМІ України (47\%), громадським організаціям (46\%) [16]. Згідно з опитуванням, проведеним у липні 2020 року, рівень довіри до волонтерських організацій дещо знизився. Найчастіше громадяни України висловлюють довіру Збройним силам України (65\%), церкві (63\%), волонтерським організаціям (63\%), Державній службі з надзвичайних ситуацій (53\%), добровольчим батальйонам (53\%), Державній прикордонній службі (52\%), ЗМІ України (50\%), Національній гвардії України (49\%), громадським організаціям (47\%). Усім іншим інститутам недовіра висловлюється частіше, ніж довіра [17]. Отже, незважаючи на певні коливання рівня довіри, волонтерські організації залишаються на лідируючих позиціях.

Одним із перших нормативно-правових актів, що засвідчив важливість волонтерської діяльності на державному рівні, стало розпорядження Президента України від 22 березня 2001 р. № 67/200-1 рп, «Про організацію проведення в Україні у 2001 р. Міжнародного року волонтерів», що зобов’язало органи державної влади забезпечити підтримку громадським організаціям. Офіційне визнання волонтерство в Україні отримало в Постанові Кабінету Міністрів від 10 грудня 2003 р. № 1895 «Про затвердження Положення про волонтерську діяльність у сфері надання соціальних послуг» [18]. 19 квітня 2011 р. № 3236-VI прийнято Закон України «Про волонтерську діяльність». Документ є чинним, його поточна редакція від 03.07.2020 р. [19]. У ст. 1 цього Закону зазначено, що волонтерська діяльність $\epsilon$ формою благодійної діяльності. Отже, Закон України «Про благодійну діяльність та благодійні організації» від 05.07.2012 р. № 5073-VI значною мірою розширює законодавчу базу волонтерського руху [20]. 30 жовтня 2014 року Міністерство фінансів України видало Наказ № 1089 «Про затвердження Порядку формування та ведення Реєстру волонтерів антитерористичної операції» відповідно до Закону України від 2 вересня 2014 року № 1668-VII «Про внесення змін до Податкового кодексу України щодо деяких питань оподаткування благодійної допомоги» та п. 2-1 розділу VII «Прикінцеві положення» Закону України «Про благодійну діяльність та благодійні організації». Цей Порядок було розроблено відповідно до законів України «Про благодійну діяльність та благодійні організації» та «Про волонтерську діяльність» [21]. Згідно із Порядком Державна фіскальна служба України створює та адмініструє Реєстр в електронній формі та щодекади оприлюднює на офіційному вебсайті ДФС. Відомості про волонтерів АТО, які містяться в Реєстрі, є інформацією з обмеженим доступом [22].

Страхування життя і здоров' я волонтерів на період провадження ними волонтерської діяльності здійснюється відповідно до Закону України «Про страхування» [23]. Крім того, згідно з Постановою Кабінету Міністрів України від 19 серпня 2015 р. № 604 про «Деякі питання виплати одноразової грошової допомоги в разі загибелі (смерті) або інвалідності волонтера внаслідок поранення (контузії, травми або каліцтва), отриманого під час надання волонтерської допомоги в районі проведення антитерористичної операції, здійснення заходів із забезпечення національної безпеки і оборони, відсічі і стримування збройної агресії Російської Федерації в Донецькій та Луганській областях, бойових дій та збройного конфлікту» встановлено порядок та умови відповідних виплат [24].

Волонтерська діяльність має значну кількість напрямів: надання безоплатної, добровільної допомоги: малозабезпеченим, хворим, особам з інвалідністю та людям похилого віку, громадянам, що постраждали внаслідок надзвичайних ситуацій будь-якого походження, сприяння або проведення громадських заходів, допомога ліквідації наслідків надзвичайних ситуацій, природоохоронна діяльність, надання волонтерської допомоги Збройним силам України та інше. У ч. 3 ст. 1 Закону України «Про волонтерську діяльність» докладно перелічено напрями, за якими здійснюється волонтерська діяльність [19].

На сайті Українського Форуму Благодійників розміщено інфографіку по роках, з 2015 по 2019. Згідно з опублікованими статистичними даними розподіл витрат за сферами надання благодійної допомоги мав певні пріоритети: у 2015 році - соціальний захист (58,7\% - 427016179 грн), охорона здоров’я (14,9\% 108169139 грн), економічний розвиток (8,3\% - 60540814 грн), допомога армї (6,9\% - 50139998 грн); у 2016 році - охорона здоров’я (57,2\% - 863705137 грн), соціальний захист (30,6\% - 462420486 грн.); у 2017 році - охорона здоров'я (69,2\% - 1705232216 грн.), соціальний захист (24,1\% - 595146448 грн); у 2018 році - охорона здоров’я (57,5\% - 1046414464 грн), соціальний захист (33,8\% - 615659342 грн); у 2019 році - соціальний захист (48,5\% - 370802848 грн), охорона здоров’я (23,1\% - 176612820 грн), 
економічний розвиток (11,2\% - 85718084 грн), інше (10,4\% - 79427647 грн) [25]. Отже, найбільш пріоритетними напрямами благодійної допомоги протягом п'яти років були соціальний захист і охорона здоров’я. 32015 до 2018 року включно спостерігається стале зростання благодійної допомоги. У 2019 році відбулося значне зменшення обсягів витрат на благодійність. Причинами цього можуть бути політична та економічна криза в країні, психологічний стан людей.

Дані про співвідношення кількості волонтерів і працівників благодійних організацій вказують на значну перевагу в бік волонтерів: 2015 рік - волонтерів (маленьких, середніх, великих) - 24 932, працівників благодійних організацій - 812; 2016 рік - волонтерів - 14015 , працівників благодійних організацій - 1 407; 2017 рік - волонтерів - 13 327, працівників благодійних організацій - 1 849; 2018 рік - волонтерів - 9 569, працівників благодійних організацій - 1 518; 2019 рік - волонтерів - 8 195, працівників благодійних організацій - 1482 . Кількість волонтерів у визначені роки значно перевищувала кількість працівників благодійних організацій, водночас простежується значне падіння кількості волонтерів із 2015 до 2019 року, насамперед через зменшення волонтерів середньої ланки: 2015 рік - 23 018, 2019 рік 2577 осіб. Водночас, зросла чисельність великих волонтерів: 2015 рік - 995, 2019 рік - 4863 особи [25]. Отже, волонтерський рух еволюціонує, поступово переходячи від стихійності до системності. Що стосується кількості організацій та установ, що залучають до своєї діяльності волонтерів, зокрема іноземців та осіб без громадянства для провадження волонтерської діяльності на території України, станом на 28.12.2020 року їх налічується 549 [26].

Волонтери та організації волонтерів поступово почали переходити від хаотичної допомоги, зокрема Збройним силам України, до систематизованої, почали спеціалізуватися за окремими напрямами. Так, вже в 2015-2016 роках «Повернись живим» спеціалізується на закупівлі тепловізорів, "CombatUA" навчає інструкторів і ремонтує оптичну техніку, «Армія SOS» займається безпілотниками та програмою управління артилерією, «Народний тил» - автомобілями та медициною, «Сестри перемоги» - розвідкою та аеророзвідкою, «Народний проект», окрім високотехнологічного забезпечення армії (безпілотниками, дистанційними модулями, польовими бліндажами, снайперської оптикою), підтримує розвиток медичних технологій і займається військовими IT-розробками [27].

У 2014-2015 роках волонтерський рух охопив територію всієї України. Окрім загальноукраїнських волонтерських проєктів, почали активно організовуватися волонтерські організації в усіх областях. Зокрема, в Миколаєві з'явилися волонтерські, громадські організації «Миколаївське народне ополчення», група «Нагодуй смачно героїв», «В'язальна сотня», «Кулінарна сотня», група «Кікімора», в Южноукраїнську - Благодійний Фонд Миротворець, «Кулінарна дюжина», в Очакові - «Виготовлення маскувальної сітки».

Не всі волонтерські групи, організовані 2014 року, залишилися до наших днів. Але група «Кікімора» 3 Миколаєва, створена шість років тому, залишилася чи не єдиною, яка продовжує виробляти маскувальні засоби та відправляе їх на фронт різним військовим підрозділам. Зазвичай розмір одної сітки становить 6 на 9 м, втім виготовляли і більші - 18 на 20 м. Станом на 2020 рік у групі постійно працюють 25-30 дівчат, саме вони починали справу і стали основою групи. Деякі працюють дистанційно: вдома розрізають тканини на стрічки та приносять їх до місця, де працює група [28].

Ще в липні 2014 року в Миколаєві створено кімнату для відпочинку військових. Перші дві кімнати для відпочинку для військових були відкриті у Харкові та Дніпрі. Третя кімната у Миколаєві. Організатором став волонтер Денис Барашковський. Нині в кімнаті зберігається одна 3 найбільших колекцій шевронів, які залишають військові на згадку. Щодня до волонтерського посту звертається близько 50 бійців. На посту 20 волонтерів чергують змінами. Серед них $є$ колишні військовослужбовці, громадські діячі та студенти [29].

Але не все так прекрасно, як здається. Ще в 2016 році у волонтерському русі почало накопичуватись розчарування у сенсі своєї роботи. У соціальних мережах волонтери почали писати про численні випадки, коли на базарах і в Інтернеті пропонувались для продажу сухі пайки, військове взуття та одяг, наводили десятки фактів безгосподарності - дорога термобілизна, привезена солдатам, не пралась, а викидалась; сотні буржуйок розкидані в тилу, а на передовій їх не вистачало. Тому багато активних волонтерів почали говорити про емоційне вигорання, відсутність бажання далі займатись волонтерством. Про ці та інші проблеми на своїх сторінках у соцмережах писали волонтери Ю. Євдокимова, О. Коваленко, Ю. Матвієнко, А. Опанасюк та багато інших. Нині волонтерські організації змінюють напрями діяльності. Їхня діяльність спрямована на посилення контролю і допомогу тиловій службі, сприяння в ефективній логістиці, збереженні, захисті майна від крадіжок. Саме в допомозі бійцям ефективно добитись належного і своєчасного постачання, юридичній, інформаційній, освітній підтримці і є сенс сучасної роботи волонтерів [30]. 
Волонтерський рух в Україні за останні роки пережив неймовірний підйом і падіння, захоплення і розчарування. Поряд із перемогами з'явились і проблеми. Але цей процес $є$ закономірним, тому що пов'язаний з еволюційними змінами суспільства. Волонтери будуть потрібні українській армії доти, доки триває війна, волонтери будуть потрібні суспільству доти, доки це суспільство існує.

\section{Література:}

1. Балухтіна О.М. Напрями волонтерської діяльності в сучасній Україні. Слов'янський світ у контексті сталого розвитку : матеріали X міжнар. наук.-практ. конф. (25 верес. 2020 р.). С. 3-12. URL: http://eurasian-institute.org/images/ conference/25.09.2020/tezy.pdf

2. Голуб В.Л. Волонтерська діяльність в системі взаємовідносин держави та суспільства : дис. ... канд. наук із держ. управ. : 25.00.01. Київ, 2016. 247 с. URL: http://academy.gov.ua/pages/dop/137/files/59f33cfd-ca50-4ada-ba6e838a166ddcbc.pdf

3. Єсіна Н.О. Поняття та сутність волонтерської діяльності в Україні. Сучасне суспільство: політичні науки, соиіологічні науки, культурологічні науки. 2017. Вип. 1 (13). С. 73-80. DOI: https://doi.org/10.5281/zenodo.580256

4. Кожухаренко Л. Полідисциплінарність досліджень волонтерського руху вітчизняними та зарубіжними науковцями. Eminak: Scientific Quarterly Journal. 2018. T. 2. № 3 (23). C. 117-123. URL: https://www.eminak.net.ua/index.php/ eminak/article/view/137

5. Костенко А.О. Волонтери XXI століття : збірник пошук. роб. обл. військово-патріотичного конкурсу, присвяченого героям-захисникам незалежної та суверенної України / уклад. А.О. Костенко. Черкаси, 2020. 57 с. URL: http://ckoblsutur.ucoz.ua/docs/2/zbirka_2020_4_ch_compressed.pdf

6. Діяльність українських благодійних організацій. Дослідження виконане CORESTONE GROUP та GFK UKRAINE на замовлення Фонду родини Загорій. URL: https://zagoriy.foundation/wp-content/uploads/2019/11/charity_funds_ report.pdf

7. Горєлов Д.М., Корнієвський О.А. Волонтерський рух: світовий досвід та українські громадянські практики : аналіт. доп. Київ : НІСД, 2015. 36 c. URL: http://old2.niss.gov.ua/content/articles/files/volonter-697e4.pdf

8. Омецінська М.В. Особливості становлення вітчизняного меценатства. Актуальні проблеми міжснародних відносин. 2011. Вип. 103 (Ч. 1). С. 191-197. URL: http://journals.iir.kiev.ua/index.php/apmv/article/viewFile/1628/1541

9. Матяш M. Українське волонтерство - явище унікальне. Йому завдячуємо суверенітетом. URL: https://www.ukrinform.ua/rubric-society/2324579-ukrainske-volonterstvo-avise-unikalne-jomu-zavdacuemosuverenitetom.html (дата звернення: 20.01.2021).

10. Загальнонаціональне дослідження. Волонтерство в Україні. United Nations Ukraine. URL: http://www.un.org.ua/ images/volunteer.pdf (дата звернення: 20.01.2021).

11. Розвиток благодійності в Україні. Національний інститут стратегічних досліджень : аналітична записка. URL: https://niss.gov.ua/en/node/191 (дата звернення: 20.01.2021).

12. CAF WORLD GIVING INDEX 10 th edition. Ten years of giving trends. October 2019. URL: https://www.cafonline.org/ docs/default-source/about-us-publications/caf_wgi_10th_edition_report_2712a_web_101019.pdf (дата звернення: 20.01.2021).

13. Загальнонаціональне опитування щодо громадського залучення в рамках Програми сприяння громадській активності «Долучайся!». URL: https://dif.org.ua/article/dopomozhi-sobi-sam-ukraintsi-rozcharovani-v-reformakh-ale-gotovipidtrimuvati-odne-odnogo-ta-svoi-gromadi (дата звернення: 20.01.2021).

14. Громадянське суспільство в період пандемії: як вона вплинула на громадську активність : опитування Фонду «Демократичні ініціативи» 315 квітня по 1 травня 2020 року серед представників громадських організацій. URL: https://dif.org.ua/article/gromadyanske-suspilstvo-v-period-pandemii-yak-vona-vplinula-na-gromadsku-aktivnist (дата звернення: 20.01.2021).

15. Ставлення громадян України до суспільних інститутів, електоральні орієнтації: результати соціологічного дослідження. Київ : Центр Разумкова, 2017. URL: http://razumkov.org.ua/uploads/socio/Press0417.pdf (дата звернення: 20.01.2021).

16. Рівень довіри до суспільних інститутів та електоральні орієнтації громадян України: дослідження Центру Разумкова 321 по 26 березня 2019 p. URL: https://razumkov.org.ua/napriamky/sotsiologichni-doslidzhennia/riven-doviry-dosuspilnykh-instytutiv-ta-elektoralni-oriientatsii-gromadian-ukrainy-2 (дата звернення: 20.01.2021).

17. Початок нового політичного року: довіра до соціальних інститутів (липень 2020 р.) : дослідження Центру Разумкова спільно з Фондом «Демократичні ініціативи» імені Ілька Кучеріва 33 по 9 липня 2020 p. URL: https://dif.org.ua/ article/pochatok-novogo-politichnogo-roku-dovira-do-sotsialnikh-institutiv-lipen-2020r (дата звернення: 20.01.2021).

18. Мазій І.В. Аналіз нормативно-правового забезпечення волонтерської діяльності в Україні. Інвестииії: практика та досвід. 2018. № 7. C. 114-118. URL: http://www.investplan.com.ua/pdf/7_2018/26.pdf

19. Про волонтерську діяльність : Закон України від 19.04.2011 p. № 3236-VI. Дата оновлення: 03.07.2020. URL: https://zakon.rada.gov.ua/laws/show/3236-17\#Text (дата звернення: 20.01.2021).

20. Про благодійну діяльність та благодійні організації : Закон України від 05.07.2012 р. № 5073-VI. Дата оновлення: 27.02.2020. URL: https://zakon.rada.gov.ua/laws/show/5073-17\#Text (дата звернення: 20.01.2021).

21. Про затвердження Порядку формування та ведення Реєстру волонтерів антитерористичної операції : Наказ Міністерства фінансів України від 30.10.2014 p. № 1089. URL: https://zakon.rada.gov.ua/laws/show/z1471-14\#Text

22. Державна фіскальна служба України. Офіційний портал. URL: www.sfs.gov.ua 
23. Про страхування : Закон України від 07.03.1996 р. № 85/96-BР. Дата оновлення: 10.12.2020. URL: https://zakon.rada.gov.ua/laws/main/85/96-\%D0\%B2\%D1\%80\#Text (дата звернення: 21.01.2021).

24. Деякі питання виплати одноразової грошової допомоги у разі загибелі (смерті) або інвалідності волонтера внаслідок поранення (контузії, травми або каліцтва), отриманого під час надання волонтерської допомоги в районі проведення антитерористичної операції, здійснення заходів із забезпечення національної безпеки і оборони, відсічі і стримування збройної агресії Російської Федерації у Донецькій та Луганській областях, бойових дій та збройного конфлікту : Постанова Кабінету Міністрів України від 19.08.2015 р. № 604. Дата оновлення: 31.10.2020. URL: https://zakon.rada.gov.ua/laws/show/604-2015-\%D0\%BF\#n10 (дата звернення: 21.01.2021).

25. Сайт Українського Форуму Благодійників. Інфографіка. URL: https://rating.ufb.org.ua/rating/blago-charts (дата звернення: 21.01.2021).

26. Міністерство соціальної політики України. Інформація про організації та установи, що залучають до своєї діяльності волонтерів, зокрема іноземців та осіб без громадянства для провадження волонтерської діяльності на території України. URL: https://www.msp.gov.ua/timeline/?t=159\&from=\&till=\&m=6\#tagpanel (дата звернення: 21.01.2021).

27. Макашова Л. Добровольці і волонтери. Чи допомагають армії на третій рік війни. URL: https://espreso.tv/ article/2016/06/10/dobrovolci_i_volontery_chy_lyshyvsya_entuziazm_na_tretiy_rik_viyny (дата звернення: 21.01.2021).

28. Івашко О. У Миколаєві «Кікімора» плете маскувальні сітки. Урядовий кур'єр. 2020.30 листопада. URL: https://ukurier.gov.ua/uk/news/u-mikolayevi-kikimora-plete-maskuvalni-sitki/ (дата звернення: 21.01.2021).

29. Волонтери відзначають річницю заснування поста для військовослужбовців. URL: https://mk.suspilne.media/ news/29900 (дата звернення: 21.01.2021).

30. Матяш М. Українське волонтерство - явище унікальне, але не без проблем. URL: https://www.ukrinform.ua/rubricsociety/2342731-ukrainske-volonterstvo-avise-unikalne-ale-ne-bez-problem.html (дата звернення: 21.01.2021). 